\title{
KAJIAN PENERAPAN REGULATOR TEKANAN RENDAH BERDASARKAN SNI 7369:2012
}

\author{
The Study of Low Pressure Regulator Implementation Based On SNI 7369: 2012
}

\author{
Gugum Gumilar dan Rita Normalia \\ Balai Besar Logam dan Mesin, Kementerian Perindustrian \\ Jl. Sangkuriang No 12, Bandung \\ E-mail: gugum@kemenperin.go.id
}

\begin{abstract}
Abstrak
Penerapan standar produk merupakan salah satu langkah perlindungan Pemerintah yang ditujukan untuk memberikan manfaat khususnya untuk pelaku usaha dan konsumen sebagai filter bagi barang/jasa berkualitas sebelum konsumen mengalami kerugian akibat mengkonsumsi barang dan/atau jasa dengan kualitas yang rendah. Penelitian ini bertujuan untuk mengetahui kesesuaian produk regulator tekanan rendah yang telah beredar dipasaran dengan standar SNI 7369:2012, melalui pengambilan contoh produk di pasaran dan dilakukan proses uji terhadap produk regulator tersebut. Telah dilakukan pengujian produk SNI wajib yaitu uji unjuk kerja dan konstruksi pada sampel regulator bertekanan rendah untuk tabung baja LPG yang diambil melalui survei pasar di beberapa kota yang mewakili provinsi Jawa Barat, Banten, dan DKI Jakarta. Uji unjuk kerja meliputi uji bunyi dan getaran, tekanan keluar, tekanan pengaman (lock up), ketahanan jatuh, dan uji kebocoran, sedangkan uji konstruksi yaitu uji pada bagian penyambung katup baja, saluran masuk dan saluran keluar. Hasil uji contoh produk regulator tekanan rendah untuk tabung baja LPG yang beredar di pasaran menunjukkan bahwa sekitar $37,5 \%$ tidak memenuhi standar. Hasil uji tersebut juga menunjukan sekitar 18,8 \% tidak memenuhi syarat mutu unjuk kerja dan $25 \%$ tidak memenuhi syarat kontruksi.
\end{abstract}

Kata kunci: regulator tekanan rendah, Standar Nasional Indonesia (SNI), gas LPG

\begin{abstract}
Abstrak
The application of products standard is one of the Government's protective ways that aimed at providing benefits to businesses and consumers as a filter for quality goods/services before consumers make an issue of spending low-quality goods and / or services. This research is aiming to study the conformity of low pressure gas regulator which has been on the market to SNI 7369:2012. The mandatory SNI product testing has been carried out consisting of performance and construction tests on low pressure regulator samples of LPG steel tube that taked through market surveys in several cities representing provinces of West Java, Banten, and DKI Jakarta. Performance test with parameters: sound and vibration test, exit pressure, safety pressure, drop resistance, and leakage test, while construction test which is a test on the connector of the steel valve, inlet and outlet. The test results of low pressure gas regulators sampling products shows 37,5\% does not meet the standards. The test results also showed that around $18.8 \%$ did not meet the performance quality requirements and $25 \%$ did not meet the construction requirements.
\end{abstract}

Key word: low pressure gas regulator, Standar Nasional Indonesia (SNI), LPG gas.

\section{PENDAHULUAN}

Standar Nasional Indonesia (SNI) diterapkan secara wajib maupun sukarela diberbagai sektor industri sebagai upaya perlindungan terhadap industri dalam negeri sekaligus terhadap konsumen di Indonesia. Regulator gas bertekanan rendah sebagai perangkat yang terdapat hubungannya dalam penggunaan tabung gas LPG merupakan salah satu produk yang termasuk dalam SNI wajib. Regulator adalah suatu alat yang fungsinya untuk menghubungkan antara selang dan katup tabung gas (Siswanto dan Hafid, 2017).

Pentingnya fungsi dari regulator tekanan rendah pada tabung LPG, mendorong pemerintah untuk melakukan perlindungan terhadap konsumen dalam pemakaian regulator agar mengurangi kecelakaan yang disebabkan oleh tidak terjaminnya mutu atau kualitas regulator dengan cara memasukkan produk tersebut ke dalam SNI wajib. Menurut Utomo (2012) "dengan diberlakukannya SNI wajib 
diharapkan produk regulator gas dipasaran aman dan layak digunakan oleh masyarakat".

Terdapat laporan dari hasil pengawasan yang menyatakan bahwa barang industri, khususnya regulator tekanan rendah yang beredar di pasar tidak memenuhi ketentuan SNI, yaitu dimana spesifikasi teknis masih berada di bawah spesifikasi yang ditentukan dalam SNI. Upaya pencegahan terjadinya kerugian pada konsumen, yaitu dilakukannya pengawasan secara berkala dan dilanjutkan dengan pengujian dan serta pengkajian kualitas regulator yang berada di pasaran.

Penelitian ini bertujuan untuk mengetahui kesesuaian produk regulator tekanan rendah yang telah beredar dipasaran dengan standard SNI 7369:2012, melalui metode survei pasar dengan mengambil contoh secara acak produk regulator tekanan rendah untuk tabung baja LPG di beberapa kota yang mewakili provinsi Jawa Barat, Banten, dan DKI Jakarta. Produk regulator tersebut dilakukan pengujian rangka konstruksi dan pengujian unjuk kerja regulator secara merusak di laboratorium, kemudian dilakukan resume/rekapitulasi terhadap laporan hasil uji untuk mendapatkan gambaran produk regulator yang berada dipasaran mengenai kesesuaiannya dengan standar.

\section{TINJAUAN PUSTAKA}

Regulator tekanan rendah tabung LPG adalah alat pengatur tekanan yang dirancang khusus untuk menyalurkan, mengatur, dan menstabilkan tekanan keluaran dari tabung LPG kapasitas 3 kg sampai dengan $12 \mathrm{~kg}$ dengan tekanan keluar maksimum $5 \mathrm{kPa}$ degan sistem pengancing tipe clip-on, tipe ulir, atau tipe lainnya. (SNI 7369:2012). Menurut Sari, dkk (2016) "Regulator gas LPG berfungsi sebagai katup penutup aliran gas yang ditempatkan pada kepala tabung gas dan pada kompor gas rumah tangga, adanya regulator gas pada tabung berguna untuk mengamankan aliran gas dari tabung ke kompor gas".

Teknik sampling merupakan teknik pengambilan sampel untuk menentukan sampel yang digunakan dalam penelitian. Non probability sampling adalah teknik yang tidak memberi peluang/kesempatan yang sama bagi setiap unsur atau anggota populasi untuk dipilih menjadi sampel (Sugiyono, 2000).

Salah satu teknik non probability sampling adalah sampling aksidental (accidental sampling), yaitu teknik penentuan sampel berdasarkan kebetulan: siapa saja yang secara kebetulan bertemu dengan peneliti dapat digunakan sebagai sampel, bila dipandang orang yang kebetulan ditemui itu sesuai sebagai sumber data (Meidatuzzahra, 2019)

Statistika deskriptif berfungsi memberikan gambaran terhadap objek yang diteliti dengan pengumpulan sampel atau populasi dan penyajian suatu data sehingga memberikan informasi yang berguna (Daria, 2016). Sedangkan, metode deskriptif analitis berfungsi memberi gambaran terhadap objek yang diteliti melalui data atau sampel yang telah terkumpul, tanpa melakukan analisis dan membuat kesimpulan yang berlaku umum (Suratman, 2017).

\section{METODE PENELITIAN}

Pengkajian kesesuaian regulator tekanan rendah untuk tabung baja LPG yang beredar di pasaran dilakukan dengan metode survei pasar dengan cara pengambilan contoh produk regulator secara langsung, yaitu membeli produk regulator di toko yang menjual peralatan rumah tangga.

Teknik sampling yang digunakan dalam penelitian ini adalah accidental sampling. Menurut Dörnyei dalam Etiken (2016) convenience sampling (dikenal juga sebagai haphazard sampling atau accidental sampling) adalah tipe dari non probability sampling dimana anggota target populasi memenuhi kriteria praktis tertentu, seperti kemudahaan akses, kedekatan geografis, ketersediaan pada waktu yang ditentukan, atau kesediaan untuk berpartisipasi diikutsertakan untuk tujuan kajian.

Pengambilan contoh dilakukan oleh pengawas (supervisi) yang bekerja sama dengan petugas pengambil contoh (PPC). Sasaran pada survei pasar ini dilakukan pada beberapa pasar di 8 kota yang mewakili 3 Provinsi yaitu DKI Jakarta, Jawa Barat dan Banten. Dari setiap kota secara acak dipilih 2 perwakilan toko, dengan masing-masing toko kemudian diambil regulator tekanan rendah yang sudah memiliki tanda kesesuaian dengan SNI 7369:2012, contoh produk regulator gas yang diambil selanjutnya diberikan identifikasi seperti yang ditunjukan pada Tabel 1.

Produk regulator tersebut kemudian dilakukan beberapa pengujian yaitu pengujian unjuk kerja dan pengujian konstruksi. Pada pengujian unjuk kerja regulator tekanan rendah dilakukan dengan parameter-parameter sebagai berikut: bunyi dan getaran, tekanan keluar, tekanan pengaman (lock-up), ketahanan jatuh, daya ketahanan pengunci, ketahanan, suhu, uji kebocoran. Pada pengujian rangka kontruksi regulator tekanan rendah dilakukan pada bagian konstruksi penyambung katup baja, saluran masuk, dan saluran keluar. Keseluruhan pengujian tersebut merupakan bagian dari 
pengujian SNI wajib yang mengacu pada SNI 7369:2012.

Penelitian ini menggunakan metode analisis deskriptif untuk menggambarkan atau menganalisis hasil penelitian. Pengkajian dilakukan dengan cara menganalisis sertifikat hasil uji laboratorium regulator tekanan rendah tabung LPG yang telah beredar di pasaran dengan SNI 7369:2012, yang akan memperlihatkan kesesuaian contoh produk regutalor tekanan rendah tersebut dengan standar yang berlaku.

Tabel 1 Identifikasi contoh produk

\begin{tabular}{llr}
\hline Provinsi & Kota & Identifikasi \\
\hline & \multirow{2}{*}{ Bogor } & X1 \\
& & X2 \\
& Depok & X4 \\
& & X5 \\
Jabar & Bekasi & X6 \\
& & X7 \\
& Sumedang & X9 \\
& & X10 \\
& Purwakarta & X11 \\
& & X12 \\
& Serang & X13 \\
Banten & & X14 \\
& Tangerang & X15 \\
& & X16 \\
DKI Jakarta & Jakarta & \\
\hline
\end{tabular}

\section{HASIL DAN PEMBAHASAN}

\subsection{Bunyi dan Getaran}

Berdasarkan SNI 7369 : 2012, regulator tekanan rendah ketika dilakukan pengujian tidak boleh bergetar dan tidak mengeluarkan bunyi pada saat dipasang di katup tabung baja LPG. Hasil pengamatan untuk semua regulator tidak berbunyi dan tidak bergetar saat dipasang dikatup tabung baja LPG seperti pada Tabel 2 . Hal ini menunjukkan bahwa produk - produk regulator yang diuji sudah memenuhi syarat mutu bunyi dan getaran.

Tabel 1 Bunyi dan Getaran

\begin{tabular}{lll}
\hline No. Contoh & Getaran & Bunyi \\
\hline X1 & Tidak & Tidak \\
X2 & Tidak & Tidak \\
X3 & Tidak & Tidak \\
X4 & Tidak & Tidak \\
X5 & Tidak & Tidak \\
X6 & Tidak & Tidak
\end{tabular}

\begin{tabular}{lll}
\hline No. Contoh & Getaran & Bunyi \\
X7 & Tidak & Tidak \\
X8 & Tidak & Tidak \\
X9 & Tidak & Tidak \\
X10 & Tidak & Tidak \\
X11 & Tidak & Tidak \\
X12 & Tidak & Tidak \\
X13 & Tidak & Tidak \\
X14 & Tidak & Tidak \\
X15 & Tidak & Tidak \\
X16 & Tidak & Tidak \\
\hline
\end{tabular}

\subsection{Tekanan Luar}

Menurut SNI 7369 : 2012, Pada saat regulator dengan tekanan masuk sebesar 0,7 $\mathrm{MPa}$ tekanan keluar minimal mencapai 2,8 $\mathrm{kPa}$ dengan toleransi $\pm 0,47 \mathrm{kPa}(4,7 \mathrm{mbar})$. Hasil pengujian untuk tekanan keluar sudah memenuhi syarat mutu tekanan keluar seperti pada Tabel 3.

Tabel 2 Tekanan keluar dan tekanan pengaman

\begin{tabular}{ccc}
\hline $\begin{array}{c}\text { No. } \\
\text { Contoh }\end{array}$ & $\begin{array}{c}\text { Tekanan } \\
\text { keluar (mbar) }\end{array}$ & $\begin{array}{c}\text { Tekanan } \\
\text { Pengaman } \\
\text { (mbar) }\end{array}$ \\
\hline X1 & 32 & 34 \\
X2 & 30 & 34 \\
X3 & 26 & 30 \\
X4 & 28 & 28 \\
X5 & 26 & 32 \\
X6 & 30 & 34 \\
X7 & 27 & 32 \\
X8 & 31 & 50 \\
X9 & 31 & 38 \\
X10 & 30 & 36 \\
X11 & 30 & 38 \\
X12 & 32 & 25 \\
X13 & 32 & 38 \\
X14 & 30 & 32 \\
X15 & 26 & 32 \\
X16 & 32 & 28 \\
\hline
\end{tabular}

\subsection{Tekanan Pengaman (Lock-up)}

Pada saat tidak ada arus aliran keluar, tekanan pada pengaman tidak boleh melebihi 4,1 kPa (41 mbar). Hasil pengujian umumnya sudah memenuhi syarat mutu tekanan pengaman, hanya ada satu produk regulator yang tidak lolos uji (X8) dengan tekanan yang melebihi standar seperti pada Tabel 3.

\subsection{Ketahanan Jatuh}

Regulator dijatuhkan pada ketinggian satu meter dari permukaan lantai dengan persyaratan (a) Tidak retak maupun pecah pada bahan 
badan regulator secara visual

(b) Tidak retak pada mekanisme

Hasil pengujian menunjukkan bahwa semua produk regulator yang diuji sudah memenuhi syarat mutu ketahanan jatuh seperti pada Tabel 4.

Tabel 3 Ketahanan jatuh

\begin{tabular}{lll} 
No. Contoh & Retak / Pecah & $\begin{array}{l}\text { Retak } \\
\text { mekanisme }\end{array}$ \\
\hline X1 & Tidak & Tidak \\
X2 & Tidak & Tidak \\
X3 & Tidak & Tidak \\
X4 & Tidak & Tidak \\
X5 & Tidak & Tidak \\
X6 & Tidak & Tidak \\
X7 & Tidak & Tidak \\
X8 & Tidak & Tidak \\
X9 & Tidak & Tidak \\
X10 & Tidak & Tidak \\
X11 & Tidak & Tidak \\
X12 & Tidak & Tidak \\
X13 & Tidak & Tidak \\
X14 & Tidak & Tidak \\
X15 & Tidak & Tidak \\
X16 & Tidak & Tidak \\
\hline
\end{tabular}

\subsection{Daya Ketahanan Pengunci}

Pengunci diputar atau buka tutup minimal sebanyak 5000 kali dengan cara menutup pada katup tabung baja LPG tidak boleh ada tanda keausan, kerusakan pada sistem pengunci. Hasil pengujian menunjukkan bahwa semua produk regulator yang diuji sudah memenuhi syarat mutu daya ketahanan pengunci seperti pada Tabel 5.

Tabel 4 Daya ketahanan pengunci

\begin{tabular}{|c|c|c|c|}
\hline \multirow{2}{*}{$\begin{array}{l}\text { No. } \\
\text { Contoh }\end{array}$} & \multicolumn{3}{|c|}{$\begin{array}{c}\text { Kerusakan saat diputar atau } \\
\text { buka tutup }\end{array}$} \\
\hline & 1500 & 3500 & 5000 \\
\hline $\mathrm{X} 1$ & Tidak & Tidak & Tidak \\
\hline $\mathrm{X} 2$ & Tidak & Tidak & Tidak \\
\hline X3 & Tidak & Tidak & Tidak \\
\hline X4 & Tidak & Tidak & Tidak \\
\hline X5 & Tidak & Tidak & Tidak \\
\hline $\mathrm{X} 6$ & Tidak & Tidak & Tidak \\
\hline X7 & Tidak & Tidak & Tidak \\
\hline$x 8$ & Tidak & Tidak & Tidak \\
\hline X9 & Tidak & Tidak & Tidak \\
\hline X10 & Tidak & Tidak & Tidak \\
\hline X11 & Tidak & Tidak & Tidak \\
\hline X12 & Tidak & Tidak & Tidak \\
\hline X13 & Tidak & Tidak & Tidak \\
\hline$X 14$ & Tidak & Tidak & Tidak \\
\hline X15 & Tidak & Tidak & Tidak \\
\hline X16 & Tidak & Tidak & Tidak \\
\hline
\end{tabular}

\subsection{Ketahanan Penggunaan}

Ketahanan regulator minimal sebanyak 50.000 kali laju aliran dengan tekanan masuk sebesar 0,7 MPa (100 psi) dengan cara mengisi dan melepaskan udara dan tidak mengalami kebocoran dan toleransi tekanan pengaman (lock-up) tidak boleh melebihi $110 \%$. Tekanan pengaman tidak melebihi $4,1 \mathrm{kPa}$. Hasil pengujian umumnya sudah memenuhi syarat mutu ketahanan, hanya terdapat satu produk regulator yang tidak memenuhi (X8) dengan tekanan pengamanan yang melebihi standar seperti pada Tabel 6.

Tabel 5 Ketahanan

\begin{tabular}{|c|c|c|c|c|c|}
\hline \multirow{2}{*}{$\begin{array}{l}\text { No. } \\
\text { contoh }\end{array}$} & \multicolumn{5}{|c|}{$\begin{array}{c}\text { Tekanan keluar (mbar) pada laju } \\
\text { aliran } 10000 \text { ke - }\end{array}$} \\
\hline & 1 & 2 & 3 & 4 & 5 \\
\hline X1 & 34 & 34 & 32 & 34 & 34 \\
\hline$X 2$ & 40 & 40 & 40 & 39 & 39 \\
\hline X3 & 30 & 30 & 30 & 31 & 30 \\
\hline$X 4$ & 28 & 30 & 28 & 28 & 29 \\
\hline$\times 5$ & 34 & 36 & 34 & 34 & 34 \\
\hline X6 & 39 & 39 & 39 & 40 & 40 \\
\hline X7 & 32 & 33 & 32 & 32 & 32 \\
\hline X8 & 48 & 50 & 48 & 50 & 48 \\
\hline X9 & 38 & 40 & 38 & 38 & 38 \\
\hline X10 & 34 & 36 & 34 & 34 & 34 \\
\hline $\mathrm{X} 11$ & 35 & 36 & 35 & 36 & 35 \\
\hline X12 & 24 & 24 & 25 & 24 & 24 \\
\hline X13 & 38 & 38 & 37 & 38 & 38 \\
\hline X14 & 32 & 33 & 32 & 32 & 33 \\
\hline X15 & 32 & 34 & 32 & 32 & 34 \\
\hline X16 & 28 & 40 & 30 & 28 & 28 \\
\hline
\end{tabular}

\subsection{Suhu}

Kinerja mekanis regulator harus dapat dioperasikan pada variasi suhu antara $0^{\circ} \mathrm{C}$ $50^{\circ} \mathrm{C}$ dan toleransi tekanan keluar dan pengaman (lock up) sebagai berikut:

- Pada suhu $0^{\circ} \mathrm{C} \pm 2^{\circ} \mathrm{C}$ dengan tekanan masuk $0,1 \mathrm{MPa}$,

- Untuk tekanan keluar berada di $2,8 \mathrm{kPa}$ $\pm 0,47 \mathrm{kPa}$

- Untuk tekanan pengaman tidak melebihi $4,1 \mathrm{kPa}$ (41 mbar)

- Pada suhu $20^{\circ} \mathrm{C} \pm 5^{\circ} \mathrm{C}$ dengan tekanan masuk 0,1 MPa

- Untuk tekanan keluar berada di $2,8 \mathrm{kPa}$ $\pm 0,47 \mathrm{kPa}$

- Untuk tekanan pengaman tidak melebihi $4,1 \mathrm{kPa}$ (41 mbar) 
- Pada suhu $20^{\circ} \mathrm{C} \pm 5^{\circ} \mathrm{C}$ dengan tekanan masuk 0,3 MPa

- Untuk tekanan keluar berada di $2,8 \mathrm{kPa}$ $\pm 0,47 \mathrm{kPa}$

- Untuk tekananp engaman tidak melebihi $4,1 \mathrm{kPa}(41 \mathrm{mbar})$

- Pada suhu $50^{\circ} \mathrm{C} \pm 5^{\circ} \mathrm{C}$ dengan tekanan masuk $0,1 \mathrm{MPa}$

- Untuk tekanan keluar berada di $2,8 \mathrm{kPa}$ $\pm 0,47 \mathrm{kPa}$

- Untuk tekanan pengaman tidak melebihi $4,1 \mathrm{kPa}(41 \mathrm{mbar})$
- Pada suhu $50^{\circ} \mathrm{C} \pm 5^{\circ} \mathrm{C}$ dengan tekanan masuk 0,6 MPa

- Untuk tekanan keluar berada di $2,8 \mathrm{kPa}$ $\pm 0,47 \mathrm{kPa}$

- Untuk tekanan pengaman tidak melebihi $4,1 \mathrm{kPa}$ (41 mbar)

Hasil pengujian umumnya sudah memenuhi syarat mutu suhu, masih ada tiga produk regulator yang tidaklolos uji (X8, X12, X13) dengan tekanan pengamanan yang melebihi standar seperti pada Tabel 7.

Tabel 6 Suhu

\begin{tabular}{cllllllllll}
\hline No. Contoh & $\mathbf{1}$ & & $\mathbf{2}$ & & $\mathbf{3}$ & Suhu & & & $\mathbf{5}$ & \\
\hline X1 & 30 & 34 & 28 & 31 & 30 & 33 & 26 & 29 & 28 & 30 \\
X2 & 30 & 38 & 28 & 33 & 30 & 34 & 27 & 30 & 29 & 32 \\
X3 & 24 & 28 & 24 & 28 & 24 & 28 & 24 & 25 & 24 & 26 \\
X4 & 26 & 29 & 24 & 25 & 24 & 26 & 24 & 25 & 24 & 25 \\
X5 & 27 & 29 & 24 & 28 & 28 & 30 & 25 & 26 & 28 & 29 \\
X6 & 28 & 30 & 26 & 29 & 29 & 31 & 26 & 28 & 28 & 30 \\
X7 & 24 & 29 & 24 & 28 & 24 & 29 & 24 & 25 & 24 & 27 \\
X8 & 24 & 30 & 26 & 45 & 31 & 49 & 22 & 44 & 28 & 50 \\
X9 & 28 & 38 & 28 & 32 & 30 & 37 & 28 & 33 & 30 & 36 \\
X10 & 28 & 32 & 26 & 30 & 28 & 32 & 26 & 29 & 28 & 31 \\
X11 & 30 & 40 & 28 & 32 & 30 & 34 & 27 & 30 & 30 & 34 \\
X12 & 24 & 28 & 19 & 20 & 20 & 21 & 16 & 18 & 22 & 24 \\
X13 & 34 & 38 & 32 & 34 & 34 & 36 & 32 & 34 & 34 & 36 \\
X14 & 30 & 33 & 26 & 28 & 28 & 30 & 36 & 28 & 29 & 31 \\
X15 & 24 & 28 & 24 & 25 & 24 & 26 & 24 & 25 & 24 & 26 \\
X16 & 26 & 27 & 24 & 30 & 27 & 32 & 24 & 28 & 26 & 30 \\
\hline
\end{tabular}

\subsection{Uji Kebocoran}

Selang disambungkan pada saluran keluar regulator, dan diisi dengan tekanan udara rendah sebesar 60 milibar selama 60 detik, bagian penutup regulator tidak boleh ada kebocoran. Regulator dipasang pada katup tabung baja dan diisi dengan tekanan udara tinggi sebesar $\quad 1,56 \mathrm{MPa}$ selama 120 detik, bagian kunci pemutar tidak boleh ada kebocoran. Hasil pengujian menunjukkan bahwa semua produk regulator yang diuji telah memenuhi syarat mutu kebocoran seperti pada Tabel 8.

Tabel 7 Uji kebocoran

\begin{tabular}{lll}
\hline No. & $\mathbf{6 0 ~} \mathbf{~ m b a r}$ & $\mathbf{1 . 5 6} \mathbf{~ M P a}$ \\
Contoh & 60 detik & $\mathbf{1 2 0}$ detik \\
\hline X1 & Tidak & Tidak \\
X2 & Tidak & Tidak \\
X3 & Tidak & Tidak \\
X4 & Tidak & Tidak \\
X5 & Tidak & Tidak \\
X6 & Tidak & Tidak \\
X7 & Tidak & Tidak
\end{tabular}

\begin{tabular}{lll} 
No. & $\mathbf{6 0} \mathbf{~ m b a r}$ & $\mathbf{1 . 5 6} \mathbf{~ M P a}$ \\
Contoh & $\mathbf{6 0}$ detik & $\mathbf{1 2 0}$ detik \\
\hline X8 & Tidak & Tidak \\
X9 & Tidak & Tidak \\
X10 & Tidak & Tidak \\
X11 & Tidak & Tidak \\
X12 & Tidak & Tidak \\
X13 & Tidak & Tidak \\
X14 & Tidak & Tidak \\
X15 & Tidak & Tidak \\
X16 & Tidak & Tidak \\
\hline
\end{tabular}

\subsection{Uji Penyambung Dimensi Katup Baja}

Penyambung katup tabung baja ini sebagai penyambung antara regulator dan katup tabung untuk menyalur LPG yang mengalir masuk ke regulator sebagaimana terlihat pada Gambar 1. Ukuran diameter dalam penyambungan katup tabung baja adalah $20_{-0}^{+0.4} \mathrm{~mm}$ 


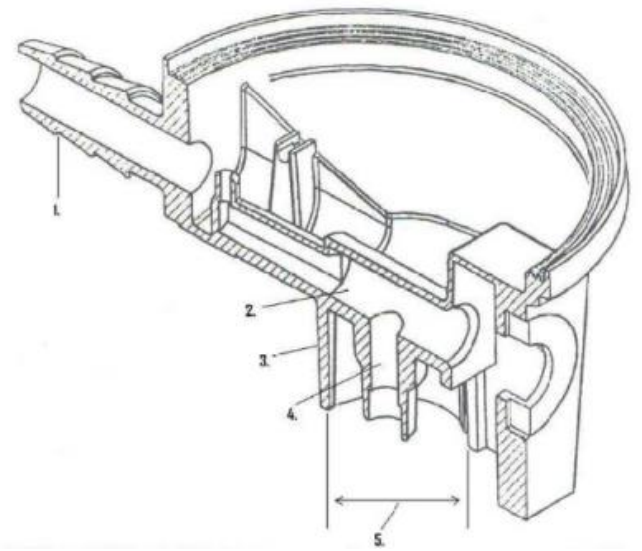

Gambar 1 Contoh penampang penyambung katup tabung baja (BSN, 2012)

Keterangan:

1. Saluran masuk

2. Ruang kunci pemutar

3. Penyambung katup tabung baja

4. Saluran masuk

5. Diameter dalam

Hasil pengujian menunjukkan bahwa umumnya produk regulator yang diuji sudah memenuhi syarat dimensi penyambung katup baja, hanya terdapat satu produk uji regulator yang melebihi syarat dimensi penyambungkatup baja yaitu untuk contoh nomor X9, hasil uji dimensi penyambung katup dapat dilihat pada Tabel 9.

Tabel 8 Dimensi penyambung katup baja

\begin{tabular}{cc}
\hline No. Contoh & $\begin{array}{l}\text { Dimensi diameter dalam } \\
(\mathbf{m m})\end{array}$ \\
\hline$X_{1}$ & 20,19 \\
$X_{2}$ & 20,21 \\
$X_{3}$ & 20,23 \\
$X_{4}$ & 20,21 \\
$X_{5}$ & 20,20 \\
$X_{6}$ & 20,22 \\
$X_{7}$ & 20,22 \\
$X_{8}$ & 20,22 \\
$X_{9}$ & 20,59 \\
$X_{10}$ & 20,20 \\
$X_{11}$ & 20,20 \\
$X_{12}$ & 20,27 \\
$X_{13}$ & 20,28 \\
$X_{14}$ & 20,22 \\
$X_{15}$ & 20,20 \\
$X_{16}$ & 20,20 \\
\hline
\end{tabular}

\subsection{Uji Dimensi Saluran Masuk dan Saluran} Keluar

Pengujian saluran masuk dan saluran keluar dilaksanakan terhadap setiap contoh produk dengan mengacu pada acuan dimensi di SNI 7369:2012 untuk ukuran bagian saluran masuk dan ukuran saluran keluar. Contoh konstruksi bangunan saluran masuk dan keluar dapat dilihat pada Gambar 2 dan Gambar 3.

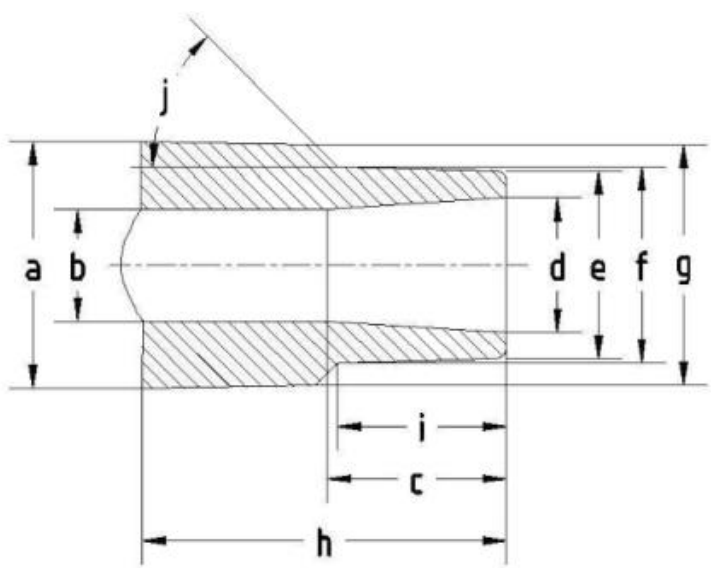

Gambar 1. Contoh konstruksi bagian saluran masuk (BSN, 2012)

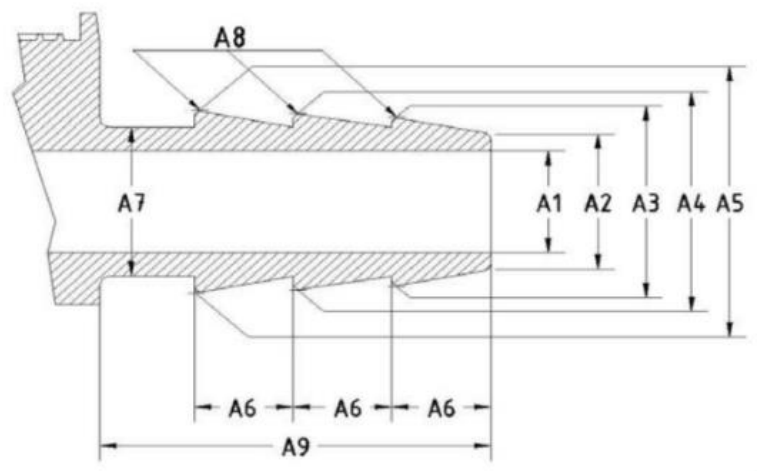

Gambar 2 Contoh konstruksi saluran keluar regulator (BSN, 2012)

Berdasarkan hasil pengujian yang telah dilaksanakan pada contoh produk, didapatkan bahwa contoh produk regulator yang telah diuji masih terdapat produk yang belum memenuhi syarat dimensi. Hasil pengujian contoh produk regulator untuk pengujian ukuran saluran masuk dan ukuran saluran keluar dapat dilihat pada Tabel 10.

Tabel 9. Hasil pemeriksaan ukuran saluran masuk dan keluar

\begin{tabular}{ccc}
$\begin{array}{l}\text { No. } \\
\text { Contoh }\end{array}$ & $\begin{array}{l}\text { Kesesuaian dengan SNI 7369:2012 } \\
\text { Ukuran saluran } \\
\text { masuk }\end{array}$ & $\begin{array}{l}\text { Ukuran saluran } \\
\text { keluar }\end{array}$ \\
\hline X1 & Sesuai SNI & Sesuai SNI \\
X2 & Sesuai SNI & Sesuai SNI \\
X3 & Tidak Sesuai & Sesuai SNI \\
X4 & SNI & Sidak Sesuai \\
X5 & SNI & Sesuai SNI \\
X6 & Sesuai SNI & Sesuai SNI \\
X7 & Sesuai SNI & Sesuai SNI \\
X8 & Sesuai SNI & Sesuai SNI \\
X9 & Sesuai SNI & Sesuai SNI \\
\end{tabular}




\begin{tabular}{ccc}
\hline No. \\
Contoh & $\begin{array}{l}\text { Kesesuaian dengan SNI 7369:2012 } \\
\text { Ukuran saluran } \\
\text { masuk }\end{array}$ & $\begin{array}{l}\text { Ukuran saluran } \\
\text { keluar }\end{array}$ \\
\hline X10 & Sesuai SNI & SNI \\
X11 & Sesuai SNI & Sesuai SNI \\
X12 & Tidak Sesuai & Sesuai SNI \\
X13 & SNI & Sesuai SNI \\
X14 & Sesuai SNI & Sesuai SNI \\
X15 & Sesuai SNI & Sesuai SNI \\
X16 & Sesuai SNI & Sesuai SNI \\
\hline
\end{tabular}

\subsection{Rekapitulasi Hasil Pengujian Produk}

Pelaksanaan pengujian dilaksanakan terhadap rangka konstruksi dan unjuk kerja regulator tekanan rendah untuk tabung baja LPG. Pelaksanaan pengujian produk regulator tekanan rendah untuk tabung baja LPG dilaksanakan di laboratorium penguji Balai Besar Logam dan Mesin (BBLM) - Kemenperin.

Hasil pengujian produk dilaporkan dalam Serifikat Hasil Uji. Resume / rekapitulasi hasil pengujian produk regulator tekanan rendah dapat dilihat pada Tabel 11 .

Tabel 10 Rekapitulasi hasil pengujian contoh produk regulator

\begin{tabular}{|c|c|c|c|}
\hline \multirow{2}{*}{ No. Contoh } & \multicolumn{2}{|c|}{ Hasil uji } & \multirow{2}{*}{ Keterangan } \\
\hline & Rangka konstruksi & Unjuk Kerja & \\
\hline $\mathrm{X} 1$ & $\sqrt{ }$ & $\sqrt{ }$ & Hasil uji sesuai SNI \\
\hline $\mathrm{X} 2$ & $\sqrt{ }$ & $\sqrt{ }$ & Hasil uji sesuai SNI \\
\hline X3 & $\mathrm{x}$ & $\sqrt{ }$ & Konstruksi saluran masuk tidak sesuai SNI \\
\hline X4 & $\mathrm{x}$ & $\sqrt{ }$ & Konstruksi saluran masuk tidak sesuai SNI \\
\hline X5 & $\sqrt{ }$ & $\sqrt{ }$ & Hasil uji sesuai SNI \\
\hline X6 & $\sqrt{ }$ & $\sqrt{ }$ & Hasil uji sesuai SNI \\
\hline $\mathrm{X} 7$ & $\sqrt{ }$ & $\sqrt{ }$ & Hasil uji sesuai SNI \\
\hline X8 & $\mathrm{x}$ & $x$ & $\begin{array}{l}\text { Konstruksi saluran masuk, unjuk kerja } \\
\text { (suhu) tidak sesuai SNI }\end{array}$ \\
\hline X9 & $\sqrt{ }$ & $\sqrt{ }$ & Hasil uji sesuai SNI \\
\hline $\mathrm{X} 10$ & $\sqrt{ }$ & $\mathrm{x}$ & $\begin{array}{l}\text { Ujuk kerja (tekanan pengaman, suhu) tidak } \\
\text { sesuai SNI }\end{array}$ \\
\hline $\mathrm{X} 11$ & $\mathrm{x}$ & $\sqrt{ }$ & Konstruksi saluran keluar tidak sesuai SNI \\
\hline $\mathrm{X} 12$ & $\sqrt{ }$ & $\sqrt{ }$ & Hasil uji sesuai SNI \\
\hline $\mathrm{X} 13$ & $\sqrt{ }$ & $\mathrm{x}$ & Ujuk kerja (suhu) tidak sesuai SNI \\
\hline $\mathrm{X} 14$ & $\sqrt{ }$ & $\sqrt{ }$ & Hasil uji sesuai SNI \\
\hline X15 & $\sqrt{ }$ & $\sqrt{ }$ & Hasil uji sesuai SNI \\
\hline $\mathrm{X} 16$ & $\sqrt{ }$ & $\sqrt{ }$ & Hasil uji sesuai SNI \\
\hline
\end{tabular}

\section{KESIMPULAN}

Hasil pengujian contoh produk regulator seperti ditunjukan pada Tabel 7 Rekapitulasi hasil pengujian menunjukkan bahwa masih terdapat contoh uji sekitar $37,5 \%$ yang masih tidak memenuhi standar, dimana sekitar $18,8 \%$ tidak memenuhi syarat mutu unjuk kerja dan $25 \%$ tidak memenuhi syarat kontruksi.

\section{UCAPAN TERIMA KASIH}

Penulis mengucapkan terima kasih kepada Direktorat Industri Permesinan dan Alat Mesin Pertanian, Kementerian Perindustrian sehingga penelitian ini dapat terselenggara, dan Erie Martides sebagai Peneliti di Telimek LIPI yang telah membimbing penulis.

\section{DAFTAR PUSTAKA}

Badan Standarisasi Nasional (2012). SNI 7369:2012. Regulator tekanan rendah untuk tabung baja LPG. Jakarta.

Dani, M., Effendi, N (2001). Analisi bahan komponen katup regulator untuk aliran gas buatan impor. Jurnal Sains Materi Indonesia. 2, 12 - 17.

Daria, D (2016). Analisis kelompok wilayah rawan penyakit malaria di provinsi Nusa Tenggara Timur tahun 2014. Skripsi. Universitas Islam Indonesia. Yogyakarta.

Etiken, I., dkk (2016). Comparison of convenience sampling and purposive sampling. American Journal of Theoritical and Applied Statistics.5(1), 1- 4. 
Gupta, A (2017). Efficacious L.P.G leakage detector and auto shut-off system using arduino uno AT mega328. International Journal of Innovative Research in Science, Engineering and Technology. 6, 19971 19978.

Ismai, L, R., dkk (2017). Rancang bangun sistem pengaman gas LPG (liquefied petroleum gas) menggunakan mikrokontroler. Youngster Physics Journal. 6, 368 - 376.

Lestari, F., Hartono, B (2012). Peningkatan pengetahuan dan keterampilan masyarakat tentang cara aman menggunakan tabung gas $3 \mathrm{Kg}$. Jurnal Kesehatan Masyarakat Nasional. 6, 225 229.

Meidatuzzahra, D (2019). Penerapan accidental sampling untuk mengetahui prevalensi akseptor kontrasepsi suntikan terhadap siklus menstruasi (studi kasus: Puskesmas Jembatan Kembar Kabupaten Lombok Barat). Jurnal Avesina. 13(1), 19 -23 .

Sari, T. I., dkk (2016). Pengujian awal ketahanan karet alam vulkanisat terhadap dimetil eter. Seminar Nasional Sains dan Teknologi 2016, Fakultas Teknik
Universitas Muhammadiyah Jakarta. TK 007.

Simurat, R (2012). Kajian eksperimental kestabilan operasi katup regulator gas Ipg terhadap kemungkinan terjadi "lock up". Skripsi. Universitas Indonesia.

Siswanto, Hendri., Hafid (2017). Rekayasa dan rancang bangun alat uji regulator tekanan tinggi tipe tekan untuk tabung LPG. Jurnal Metal Indonesia, 39.

Sugiyono (2000). Statistika Untuk Penelitian. Bandung: Alfabeta.

Suratman, D (2017). Fotografi sebagai media komunikasi antar persona dengan pendekatan nilai keislaman (pada usia1825 tahun dalam aplikasi Instagram). Skripsi. Universitas Pasundan. Bandung.

Utomo, B., dkk, (2012). Analisis sumber ketidakpastian pengukuran metode uji SNI 7369:2008 regulator tekanan rendah untuk tabung baja LPG. Jurnal Standarisasi, 14, $144-153$.

Zafer, N., Luecke, R, G (2008). Stability of gas pressure regulators. Applied Mathematical Modeling. $\quad 32, \quad 61 \quad$ - 82. 